AperTO - Archivio Istituzionale Open Access dell'Università di Torino

Temporary Employment, Demand Volatility, and Unions: Firm-Level Evidence

This is a pre print version of the following article:

Original Citation:

Availability:

This version is available http://hdl.handle.net/2318/1663865

since 2019-04-16T14:02:24Z

Published version:

DOI:10.1177/0019793917697684

Terms of use:

Open Access

Anyone can freely access the full text of works made available as "Open Access". Works made available under a Creative Commons license can be used according to the terms and conditions of said license. Use of all other works requires consent of the right holder (author or publisher) if not exempted from copyright protection by the applicable law. 


\title{
TEMPORARY EMPLOYMENT, DEMAND VOLATILITY, AND UNIONS: FIRM-LEVEL EVIDENCE
}

\author{
FRANCESCO DEVICIENTI, PAOLO NATICCHIONI, \\ AND ANDREA RICCI*
}

\begin{abstract}
This article investigates the effect of workplace unionization and product market volatility on firms' propensity to use temporary employment. Using Italian firm-level data, the authors show that volatility has a positive impact on the share of temporary contracts. The baseline estimates for the impact of unions are inconclusive, but a clear pattern emerges when a specification including an interaction term with volatility is used. This approach allows a richer characterization of the impact of workplace unionization, which is positive for low levels of volatility and negative for high levels. The authors discuss various direct and indirect mechanisms to explain this novel finding. Furthermore, they find that these effects hold only for cases in which the employer does not provide training for temporary workers, whereas temporary contracts with training provisions are not affected by unions, volatility, and their interplay.
\end{abstract}

I $\mathrm{n}$ the past few decades, most European countries have enacted a series of labor market reforms designed to endow firms with enhanced contractual flexibility in the face of the increasing economic uncertainty related to globalization and technological change. These reforms have generally been introduced "at the margin," facilitating the use of temporary contracts for new hires while leaving employment protection for open-ended contracts unaffected, ultimately producing dual labor markets in which temporary workers might be entrapped in "low-quality" jobs (Boeri 2012). For this reason, economists and policymakers are showing increased interest in identifying the determinants of temporary employment. Most of the literature has generally focused on labor supply dynamics, typically using individual data

\footnotetext{
*Francesco Devicienti is Associate Professor of Economics at the University of Torino, and Fellow at the Collegio Carlo Alberto and at the Institute for the Study of Labor (IZA). PAOLo NATICCHIONI is Associate Professor of Economics at the University of Roma Tre, and Fellow at IZA. ANDrea Ricci is Senior Researcher at the Institute for the Development of Workers' Professional Training (ISFOL). We thank ISFOL for the availability of the Rilevazione Longitudinale su Imprese e Lavoro (RIL) data and for having funded the research project. We also thank two anonymous referees and Lawrence Kahn for helpful comments that led to a significant improvement of earlier versions for the article. Additional results and copies of the computer programs used to generate the results presented in the article are available from the corresponding author at francesco.devicienti@unito.it.
}

KEYWORDs: unions, temporary workers, training, product demand volatility, firms 
from household and labor force surveys (e.g., Booth, Francesconi, and Frank 2002). The firms' demand for temporary workers has been studied rather less, despite its considerable importance, as highlighted by the empirical evidence showing that fixed-term contracts are typically favored more by firms than by workers (e.g., Francesconi and Garcia-Serrano 2004).

Apart from the focus on the difference in firing costs between open-end and temporary contracts (e.g., Kahn 2007; Boeri and Garibaldi 2007), the literature on the demand for temporary employment by firms has investigated two additional issues. The first one concerns the role of unions, which are of primary relevance in understanding the employment dynamics in European labor markets. An under-explored issue, which lies at the heart of this article, is whether the pervasive presence of unions and collective bargaining at the firm level may have contributed to the diffusion of temporary employment, partly as a way to maximize the utility of the "insider" workers (e.g., permanent and older workers) that the unions mostly represent (Saint-Paul 1996). So far, the literature has provided ambiguous evidence on this issue (e.g., Gramm and Schnell 2001; Houseman 2001; Autor 2003; Salvatori 2012). The second factor that has drawn attention in the literature analyzing the determinants of the demand for temporary employment concerns the volatility of the economic environment in which firms operate. Abraham and Taylor (1996) and Bentolila and Saint-Paul (1994), among others, argued that in more volatile environments firms increase the use of temporary employment, which can be a valuable buffer stock to adjust to fluctuations. The volatility of the economic environment, however, affects not only the behavior of the firms but also the behavior of the unions, if they anticipate the firms' hiring strategies when demand volatility increases (Freeman and Medoff 1984; Booth 1995). This issue has been largely neglected by the literature on temporary employment, despite its importance in understanding the unions' role.

To the best of our knowledge, this article is the first that focuses explicitly on the interplay between workplace unionization and product demand volatility in affecting the firms' propensity to use temporary employment. We base our empirical analysis on Italy, a country characterized by a notable increase in temporary contracts in the past few decades and by a considerable power of unions in the bargaining process. We rely on a rich firm-level data set, the Employer and Employee Survey (Rilevazione Longitudinale su Imprese e Lavoro [RIL]), conducted by the Institute for the Development of Workers' Professional Training (ISFOL) in 2005 and 2007. We supplement the RIL data with balance-sheet information from the AIDA database by Bureau van Dijk, which refers to incorporated firms in the nonfinancial private sector.

Our preferred econometric specification regresses the share of temporary workers on union presence, demand volatility, and their interaction, after controlling for an ample set of firm and labor force covariates. We deal with the potential endogeneity of workplace unionization in the context of Italian industrial relations, which resemble the institutional 
framework of other countries of continental Europe. We also discuss various channels that may explain the emergence of both a positive and a negative interaction term between volatility and union.

The issues investigated in this article are of interest along at least two dimensions. First, our investigation can enhance understanding the behavior of unions in influencing the use of temporary contracts. We shed light on the fact that unions' behavior can actually be different according to local and industry market conditions, that is, volatility.

Second, the finding of some unexplored unions' behavioral subtleties has relevance from a policy point of view. A lively and important debate on industrial relations is ongoing in Europe. In many countries, the core of industrial relations takes place at the national-sectoral level, with little room left at the local and firm level. By focusing on the behavior of unions at the local level, we contribute to the policy debate about decentralization of the industrial relation.

Another contribution offered by this article lies in the investigation of whether the effects of union presence and demand volatility on the use of temporary employment are heterogeneous across different types of temporary contracts. In particular, we distinguish between fixed-term contracts without any training clauses and temporary contracts for which a training clause is expressly introduced by the labor legislation. The difference between these types of temporary contracts appears crucial for firms' personnel strategies, and the contracts have different implications for the employment prospects and the welfare of workers and hence of unions (Berton, Devicienti, and Pacelli 2011).

\section{The Related Literature}

Temporary contracts have been widely studied in the past few decades. Attention has been given to the alleged beneficial impacts of unemployment reduction, especially for young workers (OECD 2008), as well as to the potential negative effects for the welfare of workers (Blanchard and Landier 2002; Booth et al. 2002; Boeri 2012) and on labor productivity (Battisti and Vallanti 2013; Cappellari, Leonardi, and Dell'Aringa 2012; Damiani, Pompei, and Ricci 2014).

Note that the majority of the applied research on this issue is based on individual data that are unlikely to account appropriately for the firms' incentives to hire temporary workers. Indeed, the available evidence shows that a substantial share of temporary employment appears to be involuntary on the part of the worker (Booth and Francesconi 2003). This result suggests that firms' characteristics and personnel policies play a key role in determining the diffusion of temporary contracts. For instance, Caggese and Cuñat (2008) make use of firm panel data to show that financially constrained firms use temporary workers more intensively than do financially unconstrained firms.

More in line with our article, a strand of the literature focuses on the impact of trade unions at the workplace on the use of temporary 
employment. This literature argues that the impact is potentially ambiguous, with both direct and indirect mechanisms at work. On the one hand, unions may directly contribute to a firm's strategy on labor organization and hiring policies. This may happen formally, through firm-level specific agreements with the unions, or informally, through employee consultation and involvement practices. One of the insights from the insider-outsider literature is that the unions may encourage firms to increase their use of temporary workers if they regard temporary employment acts as a buffer to isolate permanent workers from negative effects of demand uncertainty and technological shocks (Bentolila and Dolado 1994; Saint-Paul 1996). The presence of a union might also influence a firm's use of temporary workers indirectly, for example, by inducing firms to increase their share of temporary contracts to reduce a union-driven rise in labor costs (Abraham and Taylor 1996).

On the other hand, the unions may also oppose the diffusion of temporary contracts, as temporary workers are typically less unionized and less engaged in industrial relations, representing a potential threat to union strength and representativeness (Heery 2004; Salvatori 2012). Unions may also be concerned with an excessive use of fixed-term contracts because of the negative effects on social welfare and labor market cohesion (Visser 2002).

The empirical evidence for the United States is controversial. Gramm and Schnell (2001), using a small sample of firms from Alabama, found a negative correlation between union coverage and the probability of using temporary employees in the main occupational groups. Houseman (2001) studied a sample of more than 500 US firms and reached a similar conclusion. Conversely, using aggregate data from the United States, Autor (2003) found that the spread of temporary employment proved to be faster in states where the unions declined more slowly.

As for Europe, the empirical research specifically investigating the effects of unions on firms' propensity to employ temporary workers is rather scant and provides mixed results. Francesconi and Garcia-Serrano (2004) found no evidence of correlation between the share of temporary employment and unionization, using data on Spanish firms. Salvatori (2012) worked from British data and found no support for the hypothesis that firms under the threat of unionization are more likely to use fixed-term workers, and only weak evidence of negative effects for agency workers.

Of course, industrial relation practices and legislation on the utilization of fixed-term contracts differ markedly across countries, which might partly account for the divergent results. Salvatori (2009) provided the first comparative study by using workplace level data from a number of European countries. In general, he reported that unionized workplaces are more likely to use temporary contracts across Europe, and hence the unions contribute to creating labor market duality and welfare disparities between insider and outsider workers.

A potential caveat of the existing empirical literature is that the impact of unionization on the firms' use of temporary contracts is generally examined without accounting for economic uncertainty. This concern matters for at least two reasons. 
First, economic fluctuations have long been recognized as an important determinant of a firm's choice to hire on a temporary or permanent basis. For example, Bentolila and Saint-Paul (1994) showed that the difference in firing costs between permanent and temporary workers in Spain is associated with a higher cyclical elasticity (to sales) of the demand for temporary employment. In other words, firms can use temporary workers as a buffer, dropping them during recessions and allowing for a faster increase of employment during upturns. Boeri and Garibaldi (2007) found that, in the short run, Italian firms' propensity to hire on a temporary basis depends largely on the state of economic conditions and the business cycle. ${ }^{1}$ Including a measure of firms' demand volatility is important to reduce omitted variable bias when investigating the impact of unionization on the demand for temporary employment, because output volatility is likely to be correlated with both the demand for temporary employment and workplace unionization if insider workers look at the unions to make their jobs safer.

Second, no studies explore the interaction effects between the volatility of the economic environment and the presence of unions at the workplace. In particular, product demand volatility is likely to affect objectives and strategies in the bargaining process between unions and firms over various aspects of the employment relations. Economic uncertainty may therefore constitute a relevant dimension of heterogeneity in the impact of unionization on a firm's demand for temporary employment, hitherto neglected in the literature.

Our article also contributes to this literature in an additional respect. Departing from the practice in the existing papers, we investigate whether heterogeneous impacts of union and demand volatility occur across two major categories of temporary contracts that characterize most of European countries (Eurofound 2014; Cedefop 2016), namely those explicitly offering training to the worker and those for which a training clause is absent. The difference between these two types of temporary contracts appears crucial for firms' personnel strategies and has implications for the employment prospects and the welfare of workers (Berton et al. 2011).

\section{The Interplay between Unions and Volatility: Possible Explanations}

The interplay between unions and volatility is one of the main contributions of this article. To investigate the interaction term we utilize the same conceptual distinction used to analyze the impact of unions on temporary contracts. Basically, we have in mind two main categories of channels, named for simplicity "direct" and "indirect." In the direct channel, the workers' representatives directly (formally or informally) affect the firms' choices on the hiring of temporary and permanent workers. In the indirect channel, the firm hires more (or less) temporary workers in response to union

\footnotetext{
${ }^{1}$ See also Holmlund and Storrie (2002), Costain, Jimeno, and Thomas (2010), and Lotti and Viviano (2012) for related contributions.
} 
presence. Although the distinction between the two categories is not always neat, we believe that classifying the various mechanisms at play has some pedagogical value.

Broadly speaking, most of the explanations proposed relate to a general trade-off faced by unions between a buffer effect (which is potentially beneficial to the unions' core members and insiders) and a weaker bargaining position, in turn related to the fact that temporary workers typically provide lower support to unions. The equilibrium in the bargaining process with the firm will also depend on how much weight the union attaches to the objectives of employment stability versus maintaining its bargaining power and will generate either a positive or a negative interaction term.

We begin by investigating explanations entailing a positive interaction term. First, a union strongly concerned about employment stability for its core members (permanent workers) might encourage the firm to hire even more temporary workers when volatility increases (a direct effect). In the same direction, given that unions tend to restrict a firm's internal flexibility and adaptability (Gramm and Schnell 2001), an increase in volatility puts additional pressure on the firm's need to recover flexibility and to countervail any union-driven rigidity. Hence, a possible strategy for the firm is to hire more temporary workers (an indirect effect). Additionally, the firm that needs to recover flexibility in the face of increased volatility might be tempted to hire temporary workers as a weapon to undermine the union's bargaining power and hence its ability to reduce the internal flexibility and to resist organizational changes, as suggested by Hatton (2014).

What are the possible mechanisms supporting a negative interaction term? The starting point is that the union might anticipate a firm's strategy concerning the increase in temporary employment when volatility increases. The unions are also aware that temporary workers might eventually weaken the unions' bargaining power, and that firms might in fact deliberately use flexible work arrangements as a weapon for accelerating such a weakening. Hence, the union might start opposing an excessive hiring of temporary workers in the presence of raising volatility, to maintain a higher bargaining power. This result might be accomplished by means of formal bargaining between the firm and its workers (a direct effect), as well as through more informal involvement and consultation practices between the management and the employees' representatives.

The unions may also anticipate that, as volatility rises, temporary workers will be even more likely to leave the firm (because of shorter contracts, reduced probability of contract renewals, higher turnover), and to engage even less in union activity or support, which threatens the union's bargaining power. Also in this case, the unions have incentives to oppose the hiring of temporary workers as volatility rises. We expect this effect to be stronger for those temporary workers who are typically employed as a buffer stock 
(e.g., hired with contracts that do not stipulate for firm's training), which means they face a lower probability of being transformed into permanent workers and becoming union members. ${ }^{2}$

Indirect mechanisms can also give rise to a negative interaction term. For instance, the unions might opt for a cooperation strategy with the management, in response to an increase in the demand for "insurance" by workers because of higher volatility. This approach may result in wage moderation by a risk-adverse union, as suggested by the work of Guiso, Pistaferri, and Schivardi (2005). Moreover, a risk-adverse union might make concessions in terms of providing the firm with a higher internal employment flexibility, for example, forms of labor re-organization involving permanent, core workers. In both cases, these actions may ultimately reduce the firm's need to hire temporary workers.

Related indirect mechanisms are also suggested by the literature on High-Performance Human Resource Management (HRM) and cooperative industrial relations (Freeman and Medoff 1984). A number of studies suggest that firms may ameliorate their productivity by introducing new HRM practices, including comprehensive systems and procedures of employee recruitment and selection, training, incentive compensation and performance assessment, grievance and attitude assessment, employee involvement, information sharing, and improved communication (e.g., Bloom et al. 2014). As suggested in the literature (Black and Lynch 2001; Gill 2009; Pohler and Luchak 2014), the presence of unions may favor the implementation of these HRM practices through a variety of channels. For instance, under uncertainty, agreements made between managers and workers may not be legally enforceable, so the presence of unions can be of help in addressing incentive compatibility problems that may arise at the workplace (Malcomson 1983). ${ }^{3}$ In other words, in a risky economic environment and with incomplete contracts, the unions may be able to reduce free-riding problems by promoting cooperative industrial relations and employees' participation in decision making, a strategy that contributes to increased commitment between the management and the employees and contract enforcement (Kruse, Freeman, and Blasi, 2010). Accordingly, one may expect unionized firms to use less temporary employment than nonunionized ones as volatility rises: an extensive use of temporary contracts may increase workforce segmentation of the internal labor market and reduce

\footnotetext{
${ }^{2}$ For example, Cappelli and Keller (2013) found that unionization is associated with lower use of temporary workers, arguing that off-roll workers are less eligible to join the union (see also Kalleberg, Reynolds, and Marsden 2003).

${ }^{3}$ Additional channels for the implementation of HRM practices include unionization, which makes workers more willing to participate in employee involvement programs, because they feel the union will protect their employment; and negotiations between employees and the management about the introduction of new workplace practices that entail lower costs if the company has to deal with union specialists rather than individual workers. The new HRM are more likely to be accepted as the unions facilitate information sharing and communication among workers and management.
} 
worker cohesion, ultimately hurting the ability of unions in favoring the implementation of innovative HRM practices. ${ }^{4}$

To summarize, we argue that the sign and the magnitude of the interaction term is an empirical issue, which lies at the core of our econometric findings and which sheds light on the firms' hiring policies in the presence of unions and volatility in the economic environment.

\section{Institutional Background}

Italy is characterized by a two-tier bargaining system, with a dominant sectoral tier and a supplementary decentralized tier in which bargaining is usually carried out at the company level. ${ }^{5}$ The main objectives of the sectoral agreements (National Collective Labor Agreements [NCLA]) are to protect real wages and to set common economic and normative conditions for sectoral workers nationwide. At the decentralized level, it is possible to negotiate performance and productivity-related wage increases. The second-level bargaining may address a number of additional matters, such as working hours, employment training, labor organization, and union relations in order to gain flexibility for organizational changes and competitiveness. ${ }^{6}$ Agreements and conditions arrived at through bargaining at the decentralized level are typically applied to all workers in the firm (Cella and Treu 1999). Second-level bargaining is subject to the limits and provisions defined by the specific NCLAs applied in the productive unit. ${ }^{7}$

Italian law gives workers the right to join a union, engage in union activity, and organize a plant-level union representation structure. The main

\footnotetext{
${ }^{4}$ Another possible channel that we stressed in a previous version of the article concerns a "timing argument": when volatility raises, bargaining will occur more often, and because of this, the unions will be even more concerned about an excessive use of temporary workers (Addison 2014). Indeed, a recent report by the European Foundation for the Improvement of Living of Working Conditions (Eurofound 2015: 35) argued that in most EU countries the duration of collective agreements since 2008 has reduced, mainly as a result of the difficulties in agreeing to longer-term provisions in times of economic and financial turmoil and accelerated change. Coupled with anecdotal evidence from Italy, this context provides some initial support for the conjecture that firm-union bargaining becomes more frequent when volatility increases. Our data, however, do not allow us to provide any direct evidence on this issue. Moreover, from a theoretical point of view, we acknowledge it is not trivial to establish under what conditions the time-horizon of the bargaining process affects a union's support to a firm's hiring of temporary workers.

${ }^{5} \mathrm{~A}$ territorial level (mostly at the province level) also exists but is typically confined to particular industries, for example, construction and agriculture.

${ }^{6} \mathrm{No}$ official data are available on the diffusion and content of decentralized bargaining. Survey data suggest that the coverage is approximately $60 \%$ of employees and from 15 to $25 \%$ of firms (Damiani and Ricci 2014), with greater incidence in manufacturing and larger firms. A large fraction of second-level agreements (more than 60\%) contain wage increases related to productivity gains, but agreements dealing with workplace organizational changes, performance-based human resource management practices, and employment flexibility are not uncommon and broadly cover the remaining $40 \%$ of cases.

${ }^{7}$ Decentralized agreements are only supplementary to, and applicative of, the NCLAs. The possibility of opting-out or derogating from NCLAs was formally introduced only recently, after 2009, which is beyond the sample period we analyze.
} 
workplace representative body is the so-called unitary workplace union structures (Rappresentanze Sindacali Unitarie [RSU]). ${ }^{8}$ The RSU includes features of works councils (for example, worker representatives are elected by all permanent employees) but can also be associated with trade union bodies (for example, worker representatives are usually elected from competing candidates on trade unions lists). ${ }^{9}$ Hence, in Italy, union and employee representation are entrusted to a single body (single-channel representation) as opposed to a dual-channel system in which union delegates operate alongside works councils. ${ }^{10}$ Worker representatives are able to negotiate at the plant level on issues delegated from the industry-wide level, and they have rights to information and consultation (D'Amuri and Giorgiantonio 2015).

As for temporary contracts, a process of labor market deregulation started in the mid-1990s (with the "Treu package" in 1997, the Legislative Decree 368 of 2001, and the Law 30 of 2003). Similar to developments in other European countries, these reforms introduced various types of temporary contracts without changing the legislation on permanent (open-ended) contracts. Of the temporary contracts, fixed-term contracts are the most popular, at around $7 \%$ of the workforce (compared to $84 \%$ of open-end contracts). ${ }^{11}$ Permanent and fixed-term contracts differ only by virtue of a fixed term. Because of employment protection legislation, fixed-term contracts can be rescinded (or not renewed) more easily. All other working conditions, such as wages, working times, pension rights, and probation period, are identical, and firms pay the same social security contribution rates for the two types of contracts. ${ }^{12}$ A fixed-term contract can be renewed only once, and its cumulated duration cannot exceed three years with the same firm.

Apprenticeship represents another form of temporary contracts, at approximately $3 \%$ of the workforce. Firms can use this contract only for young workers (up to 30 years of age), must provide certified training and,

\footnotetext{
${ }^{8}$ According to Italian law, workers' representation can be set up in firms with more than 15 employees, at the discretional initiative of workers. Hence, not all firms with more than 15 employees are unionized. Furthermore, the national bargaining system at the industry level can introduce workers' representation in firms with fewer than 15 employees. In our sample of firms with 10 to 15 employees, the share of unionized firms is approximately $7 \%$, whereas for firms with more than 15 employees the share is approximately $50 \%$.

${ }^{9}$ Note that many features of Italian industrial relations are similar to those of other countries of continental Europe (see, e.g., OECD 2004, and Breda 2016 for France): multi-tier bargaining; no US-style "certification elections" required for union recognition; workers can be represented by more than a union at the workplace; and unions are open shop.

${ }^{10}$ Note that an alternative plant-level union body (Rappresentanza Sindacale Aziendale [RSA]) can be elected by the members of a particular union. RSUs have tended to replace RSAs, which are usually found in smaller companies and in certain sectors such as banking.

${ }^{11}$ See Cappellari et al. (2012), as reference for these labor contracts shares.

${ }^{12}$ The available empirical evidence for Italy, however, has typically documented lower wages for fixedterm workers (e.g., Picchio 2006).
} 
in exchange, are granted lower social security contributions. The maximum cumulated duration is three years. ${ }^{13}$

In general, temporary and apprenticeship workers cannot elect the RSU (and cannot be elected), although NCLAs can, and sometimes do, stipulate for the contrary. Overall, it is plausible to assume that unions mainly represent the interests of insider and/or permanent workers, which in most of the firms represent the biggest group of workers, hence including the median voter. Note that household surveys have generally documented an aging trend in union membership across Europe (e.g., Eurobarometer), a trend that is somewhat stronger in the case of the three largest Italian union confederations. As the latter maintain strong links (and influence) on the behavior of workplace unions, and given that permanent workers tend to be over-represented among older workers, one may speculate on an overrepresentation of the interests of older and/or permanent workers over those of younger and/or temporary workers, though no evidence is currently available to corroborate that observation. ${ }^{14}$

We report some evidence that the presence of trade unions at the workplace may exert an influence on a firm's demand for flexible contracts. In particular, unions and workers' representatives may be involved in shaping the firm's hiring policies through participation in firm-level specific agreements on issues not already covered by NCLAs or by tailoring the sectorwide dispositions to local circumstances. According to CNEL (2007), "numerical flexibility" and, in particular, "issues related to the use of atypical contracts" were covered in almost $50 \%$ of company-level agreements in the period 1998 to 2006, albeit the exact content of the agreements is uncertain. Union influence may also be exerted through more informal consultation and involvement practices. This channel is likely to be relevant at the productive-unit level between workers' representatives and

\footnotetext{
${ }^{13}$ Firms can also employ collaboration contracts (collaborazioni), under which the workers are to be formally considered as self-employed, although in some cases they perform tasks equal to those of employees of the firm. Because of reduced social security contributions, no training obligations, and the possibility to extend and repeat these contracts at will, firms stand to benefit from this type of contract, which represents around $3 \%$ of the workforce. Temporary agency contracts are also available to firms. Because of agency fees, the cost of these external workers is higher than in the case of permanent contracts, partly offset by lower hiring and firing costs. Their share in the workforce is still limited in Italy at only $1.5 \%$. We do not consider these two types of contracts because they are not formally employees of the firm, and because it is not possible to distinguish in our data those collaboration or agency workers who actually replace employees in the firm from those who carry out some genuine consultancy or have short-term labor relations with the firms.

${ }^{14}$ Note that we cannot exclude that unions also work in the interest of temporary contracts. Even if temporary workers cannot elect the RSU, unions might work for this group of workers since they expect that a share of temporary workers will become permanent in the future. Actually, this distinction might play a role when distinguishing between training and non-training workers. Given that the literature shows that training contracts are more widely used as stepping stones to a permanent position (Berton et al. 2011), they might be perceived by unions as closer to permanent contracts, and this difference should emerge in our empirical analysis. Unfortunately, we cannot explore this issue further because we do not have workers' individual data.
} 
intermediate managers-especially in small- to medium-size firms-though little is known on the spread of such practices (see Cerruti 2011).

\section{Data and Descriptive Statistics}

The empirical analysis is based on the Employer and Employee Survey (RIL) conducted by ISFOL in 2005 and 2007 on a nationally representative sample of firms operating in the non-agricultural private sector. The RIL survey collects a rich set of information on personnel organization, industrial relations, and other workplace characteristics. In particular, the RIL allows us to distinguish between the two different typologies of temporary contracts, that is, whether a training clause is explicitly considered. We define as "training temporary contracts" (contratti a causa mista) any apprenticeship contracts, training and work contracts (contratti di formazione lavoro), or job insertion contracts (contratti di inserimento lavorativo). The term "non-training temporary contracts" (contratti a tempo determinato) refers to any other type of fixed-term contracts that contain no training clause.

To link information on workplace characteristics to indicators of firm performance and economic volatility, we merge the RIL data set with annual balance sheets and income statement data from the Analisi Informatizzata Delle Aziende Italiane (AIDA) archive. The merge is carried out through unique company tax codes. As AIDA covers only limited companies with turnover of more than 100,000 euros, the RIL-AIDA merged sample restricts the analysis to limited companies above this (rather minimal) threshold.

Given our focus, we also exclude firms with fewer than 10 employees to retain only those firms characterized by a minimum level of organizational structure and for which the share of employees in different types of contracts can be meaningfully computed. Further, very small firms are rarely characterized by union representation. Our final sample includes more than 6,600 firms.

Table 1 displays descriptive statistics. The first four columns refer to the pooled 2005 to 2007 original RIL data, considering both the full sample (firms with at least 1 employee) and the subsample (firms with more than 10 employees). The last two columns show the descriptive statistics for the RIL-AIDA merged sample used in the article. As expected, the main differences emerge from including and excluding micro firms below 10 employees. Once we take the set of firms with more than 10 employees as our reference population, the additional restriction imposed by matching the sample with the AIDA data produces only marginal differences in the descriptive statistics.

In our final RIL-AIDA sample, the overall share of fixed-term contracts is $9.8 \%$, which can be split into the share of non-training contracts $(6.1 \%)$ and the share of training contracts $(3.7 \%)$. As for the other variables of interest, we created a dummy variable ("union" for short) that indicates 
Table 1. Descriptive Statistics and Data Selection Process

\begin{tabular}{|c|c|c|c|c|c|c|}
\hline \multirow[b]{3}{*}{ Descriptive category } & \multicolumn{4}{|c|}{$R I L$} & \multirow{2}{*}{\multicolumn{2}{|c|}{$\begin{array}{c}\text { RIL-AIDA } \\
\geq 10 \text { employees }\end{array}$}} \\
\hline & \multicolumn{2}{|c|}{ Full sample } & \multicolumn{2}{|c|}{$\geq 10$ employees } & & \\
\hline & Mean & $S D$ & Mean & $S D$ & Mean & $S D$ \\
\hline \multicolumn{7}{|l|}{ Variables } \\
\hline Share of temporary contracts & 0.100 & 0.165 & 0.096 & 0.147 & 0.098 & 0.149 \\
\hline Share of non-training temporary contracts & 0.058 & 0.134 & 0.064 & 0.133 & 0.061 & 0.134 \\
\hline Share of training temporary contracts & 0.042 & 0.105 & 0.031 & 0.071 & 0.037 & 0.076 \\
\hline Union & 0.290 & 0.454 & 0.413 & 0.492 & 0.400 & 0.491 \\
\hline Share of female workers & 0.371 & 0.289 & 0.336 & 0.261 & 0.323 & 0.267 \\
\hline Share of white collars & 0.428 & 0.320 & 0.405 & 0.300 & 0.407 & 0.297 \\
\hline Share of blue collars & 0.507 & 0.336 & 0.532 & 0.319 & 0.539 & 0.313 \\
\hline Share of trainees & 0.204 & 0.323 & 0.231 & 0.328 & 0.200 & 0.316 \\
\hline Firms age (years) & 24.181 & 17.336 & 26.774 & 18.735 & 22.229 & 16.018 \\
\hline Volatility & - & - & - & - & 0.398 & 0.201 \\
\hline \multicolumn{7}{|l|}{ Macro-region } \\
\hline North West & 0.359 & 0.480 & 0.381 & 0.486 & 0.368 & 0.482 \\
\hline North East & 0.259 & 0.438 & 0.272 & 0.445 & 0.260 & 0.439 \\
\hline Central & 0.195 & 0.396 & 0.182 & 0.386 & 0.196 & 0.397 \\
\hline South & 0.187 & 0.390 & 0.165 & 0.371 & 0.177 & 0.381 \\
\hline \multicolumn{7}{|l|}{ Sector of activity } \\
\hline $\begin{array}{l}\text { Quarrying, water, gas, and } \\
\text { electricity distribution }\end{array}$ & 0.039 & 0.193 & 0.037 & 0.189 & 0.008 & 0.088 \\
\hline Textiles & 0.143 & 0.350 & 0.158 & 0.365 & 0.129 & 0.335 \\
\hline Manufacturing & 0.099 & 0.298 & 0.110 & 0.313 & 0.180 & 0.384 \\
\hline Mechanics & 0.170 & 0.375 & 0.173 & 0.379 & 0.148 & 0.355 \\
\hline Construction & 0.107 & 0.309 & 0.110 & 0.313 & 0.161 & 0.368 \\
\hline Trade, hotels, and restaurants & 0.145 & 0.353 & 0.128 & 0.335 & 0.172 & 0.377 \\
\hline Transport and communication & 0.057 & 0.233 & 0.056 & 0.229 & 0.040 & 0.196 \\
\hline Business services & 0.121 & 0.326 & 0.110 & 0.313 & 0.073 & 0.260 \\
\hline $\begin{array}{l}\text { Education, health, and other } \\
\text { public services }\end{array}$ & 0.120 & 0.325 & 0.117 & 0.322 & 0.090 & 0.286 \\
\hline Year 2007 & 0.511 & 0.500 & 0.513 & 0.500 & 0.447 & 0.497 \\
\hline Observations & \multicolumn{2}{|c|}{11,169} & \multicolumn{2}{|c|}{7,612} & \multicolumn{2}{|c|}{6,655} \\
\hline
\end{tabular}

Notes: Sample weights used. RIL, Employer and Employee Survey; AIDA, Analisi Informatizzata Aziende Italiane.

whether workers have established any form of workers' representation at the workplace that is legally entitled to participate in the firm-level bargaining process. ${ }^{15}$ Such workplace representation is found in about $40 \%$ of the firms.

Another important variable in the analysis is the volatility measure, which is computed as the average standard deviation of log sales over the period 1997 to 2005, calculated at the three-digit classification of economic activity (NACE, over 450 sectors). We used the AIDA data set to compute our measure of volatility, as this data set has yearly information on firms' sales and

\footnotetext{
${ }^{15}$ In accordance with the institutional framework presented in the Institutional Background section, we take as an indicator of unionization the presence of either RSUs or RSAs at the workplace.
} 
numbers of employees (but not on unionization and contract types) for incorporated businesses in Italy over a relatively long time period. Note that our measure of demand volatility is computed at the sectoral level, rather than at the firm level, which helps minimize endogeneity concerns related to this variable. Table 1 shows that the demand volatility measure has a mean equal to 0.4 in the sample. Table 1 also sets out the descriptive statistics for all the other control variables used in the regression analysis.

\section{Econometric Analysis}

Our econometric analysis is performed using regression models to estimate the following equation:

$$
T C_{i t}=\beta_{1} v_{c o l}+\beta_{2} \text { union }_{i t}+\beta_{3} v_{\text {ool }} \times \text { union }_{i t}+X_{i t} \delta+\varepsilon_{i t}
$$

with $t=2005,2007 . T C_{i t}$ denotes the share of workers with a temporary contract in firm $i$ at time $t, v o l_{c t}$ is our measure of a firm's output demand volatility (in the sector $c$ to which firm $i$ belongs), and union $_{i t}$ is a dummy variable indicating union presence at the workplace. $V_{o l}{ }_{c t}^{*} u n i o n_{i t}$ is an interaction term capturing the effect of the interplay between volatility and workplace unionization on the share of fixed-term contracts.

The vector $X_{i t}$ contains firm-level control variables that may affect the dependent variable and may be correlated with workplace unionization and volatility. In all the models reported below, we include the following set of baseline control variables: the share of female workers, the shares of blueand white-collar workers, the firm's age (in years), firm-size dummies (3 classes defined in terms of employees), sector dummies (10 industries), geographical area dummies (4 macro regions), and a dummy for year 2007. In none of the cases did experimentation with models containing subsets of these basic control variables have any appreciable effect on the estimates of our relevant variables, and they are therefore not reported. Models with expanded sets of control variables are discussed below. Finally, $\varepsilon_{i t}$ is an idiosyncratic error whose properties are specified in the next section, depending on the chosen econometric approach.

\section{Endogeneity and Methodological Issues}

One of the main challenges in our empirical analysis concerns the potential endogeneity of the union variable. The existing literature suggests that a sharp causal effect can be estimated only under specific circumstances, such as the regression discontinuity designs offered by the union certification elections in the United States (DiNardo and Lee 2004; Lee and Mas 2012). Unfortunately, the institutional settings of most countries of continental Europe do not exhibit such peculiar discontinuities or other readily exploitable sources of exogenous variation. For instance, in these countries unions 
do not generally need to win a majority election to be recognized as bargaining partners.

Breda (2015) has argued that European countries have, however, other peculiar features that can be exploited for implementing an appropriate research design. He investigated the case of France, claiming that workplace unionization does not systematically target more profitable or productive firms and is obtained in a relatively large number of firms. This finding is because, under French law, it is typically very easy to organize a firm's workers in a union, since what is needed is only to find a worker who is willing to act as union representative or to contact the local union officials, who are always willing to help set up a union in a firm. For this reason, Breda (2015) assumed that his estimates were unlikely to be biased by unions selecting only the best firms, and hence, the assignment to treatment can be assumed as quasi-random, conditional on observables. In such a framework, ordinary least squares (OLS) regressions can identify a causal effect.

The discussion in Breda (2015) matters also for our research goals, since the Italian institutional framework is rather similar to the French one: as discussed in Institutional Background, it is also relatively easy and low cost to set up a union in Italy. Nonetheless, one can still question the random assignment assumption even for countries of Continental Europe for several reasons. First, even if one assumed away any self-selection on the workers' side, this might not be the case from the firms' side. For instance, some firms might have a strong preference against having a local union and may behave strategically to achieve this goal, granting workers some favorable economic and working conditions as a counterpart of an informal commitment for not setting up a local union. Second, in our analysis a number of variables might be expected to affect both a firm's union status and the propensity to hire temporary workers. An example of such variables could be the managerial culture and ability. Failing to control for these factors may potentially bias the relevant estimates. A firm culture promoting highperformance resource management practices and high investment in human capital might generate both a limited use of temporary workers (particularly of the buffer type) and a cooperative environment conducive to worker representation, and hence union presence. Third, Breda (2015) also showed that even if the union variable is considered as exogenous, its bargaining power likely depends on the share of unionized workers in the firm, which in turn can hardly be considered as exogenous to the share of temporary workers.

For these reasons, in our study we depart from Breda's (2015) empirical strategy. Starting with simple OLS models, we base our preferred econometric analyses on two alternative approaches: fixed-effect (FE) models and instrument variable (IV) models. We are aware that both methods have specific advantages and disadvantages in the context of our application. For this reason, we do not depend solely on either the FE or the IV approach and, instead, conduct our empirical analyses using both of them in parallel. 
We are more confident about the validity of our results when they are robust to the two alternative approaches. We believe we cannot do much more to improve the identification of a causal effect given the institutional framework and the available data.

An IV approach can potentially deal with time-invariant and time-variant omitted variable biases, including measurement error in union status. Of course, a major challenge-still largely ubiquitous in the literature on the effects of unions-lies in finding suitable instruments. Ideally, we would like to instrument union status in a first-differenced model. This empirical strategy would cope with firm-level time-invariant unobserved heterogeneity (by first differentiating Equation (1)), while controlling for time-specific omitted variables and measurement error in union status (through IV of the first differentiated model). It is no simple task to find valid instruments for the change in a firm's union status, however, and for this reason we had to abandon the panel IV approach.

Instead, we resort to a simpler IV framework, in which a firm's union status is instrumented by the two-year lagged mean unionization at the threedigit industry and region level. Clearly, this IV strategy means limiting the analysis to the 2007 data sample, since our main instrument is derived using the 2005 wave. ${ }^{16}$ To increase efficiency, our preferred IV specification uses the four-year lagged industry profit per employee as an additional instrument. $^{17}$

We believe that both variables make for reasonable IV candidates. Consider lagged mean unionization. First, most temporary contracts are of very short duration, on average less than a year. Hence, a two-year lag in industry-level unionization is not expected to have any direct impact on the current use of temporary employment, once current unionization at the workplace is controlled for. Although longer lags would, in principle, be desirable, we cannot construct them on the basis of the available data. ${ }^{18}$ Second, mean unionization at the industry and territorial level is a strong predictor of current workplace unionization. Empirically, this result is clearly supported by the first-stage statistics we report below. More important, the predictive power of the instrument is to be expected in light of the institutional framework discussed above. According to Italian law, workplace unionization emerges out of the initiative of a firm's workers. Setting up the process leading to workers' representation, however, requires expert knowledge and operational support, which the local structures of the union confederations are able and willing to provide. In short, past unionization at

\footnotetext{
${ }^{16} \mathrm{No}$ other data set is currently available for Italy that would allow us to compute mean unionization at a finely disaggregated level.

17"Profit per employee" is here measured by the Gross Operating Surplus available in AIDA, divided by the firm's number of employees, and then averaged at the three-digit industry level.

${ }^{18}$ The results by Salvatori (2012), showing that firms under the threat of unionization do not increase their demand for temporary employment, also offer evidence that reverse causality may not be a major concern.
} 
the industry and territorial levels acts as an incubator for workplace unionization. Moreover, the single channel of representation entails that union officials, in most cases external to the firm, are actively involved in consultation and negotiation activities. ${ }^{19}$

Turning to past profitability, this factor is also a strong predictor of current unionization. ${ }^{20}$ Past profitability is generally considered a determinant of unionization, as unions can expect to share rents where rents are sizeable. A four-year lag in industry profitability should suffice to remove concerns about possible direct effects on the current share of temporary workers. In a robustness check, we also consider a six-year lagged profit variable as an instrument. To make our case even more compelling, we experiment with specifications that include and exclude current firm profitability from the list of controls, as well as instrument using lagged firm profitability instead of lagged industry profitability.

A second solution to the potential endogeneity of union status is to assume that omitted variables are time invariant. Hence, an individualspecific intercept, $\alpha_{i}$, is added as a component of the error term in Equation (1); $\alpha_{i}$ can be freely correlated with union status or other righthand-side variables in the model. In such a framework, consistent estimates may be obtained through linear models with fixed effects (FE). Since firms are observed during two points in time (2005 and 2007) in our data, we can estimate fixed-effect models. We have to recognize, however, that limited "within" variability and the attenuation bias resulting from measurement errors-especially in fixed-effect models_might be a challenge for this identification strategy. ${ }^{21}$

Before turning to the results, we will briefly discuss the pros and cons of using linear models (as in our IV and FE regressions) as opposed to nonlinear models such as Tobit regressions. The latter are a standard choice to account for the double-censored nature of our dependent variable, the fraction of workers with a fixed-term contract lying between 0 and 1 by construction (Houseman 2001; Cappelli and Neumark 2004; Lee and Kim 2005). Linear models do not account for the censored nature of the dependent variable; however, they are better placed for dealing with the potential

\footnotetext{
${ }^{19}$ The 1993 Tripartite Agreement explicitly mentions that the competent territorial structures of the trade union associations (that have signed the NCLA applied in the productive unit) participate in collective bargaining within the firm alongside workers' representatives.

${ }^{20}$ Salvatori (2009) reports IV estimates of the effect of unions on the probability of firms employing any temporary workers, using a six-year lagged employment as an instrument for union status. The argument in favor of such an instrument is that lagged employment can be expected to be correlated with current union status, because union status is a persistent feature of the workplace, and employment size is a known determinant of union status. Our computations, however, showed that long lags of employment (which are available from the information contained in AIDA) are only weak instruments in our application, with first-stage $F$ statistics that never exceed critical values at conventional levels.

${ }^{21}$ As for the within variability, approximately $25 \%$ of firms change union status in the two years (from unionized to non-unionized and vice versa), technically providing "enough" variability for a fixed-effect estimation.
} 
endogeneity of right-hand-side variables and provide a simpler framework to compute average marginal effects in the presence of variable interactions (Angrist and Pischke 2009). ${ }^{22}$ For these reasons, our main analysis is conducted through linear models. Nevertheless, for robustness we report in the Appendix the results obtained with both standard and random-effect Tobit models, which are consistent with the results derived using linear models.

\section{Econometric Results}

\section{OLS Models}

Table 2 displays the estimated coefficients of Equation (1), focusing for the sake of brevity on only the most relevant variables. ${ }^{23}$ The first column of Table 2 sets out the OLS coefficients of a simpler version of Equation (1) that omits the interaction term. If the conditional quasi-random assumption discussed by Breda (2015) holds, then even OLS estimates can provide unbiased estimates.

Table 2 shows that economic volatility has a positive and statistically significant effect on the utilization of flexible contractual arrangements, which is consistent with the previous literature arguing that volatility encourages firms to employ temporary workers to adjust the labor input more easily. More specifically, a one standard deviation increase in volatility is associated with an increase of approximately 2 percentage points in the use of temporary contracts. This value represents quite a sizable effect, amounting to a nearly $20 \%$ increase with respect to the baseline share of temporary contracts standing at $9.8 \%$.

Column (1) also shows that the presence of a union in the workplace is associated with a lower use of temporary contracts (-2.3 percentage points). As argued above, one possible interpretation of this finding might be that temporary employees are less likely than permanent employees to be unionized and engaged in industrial relations. This result implies that hiring workers on a temporary basis may significantly weaken union bargaining power and its representativeness in industrial relations. If this is indeed so, then the unions would discourage the use of fixed-term contracts to favor outcomes for the insiders in future bargaining negotiations (Bentolila and Dolado 1994; Booth 1995).

To gain further insights into these mechanisms, we re-estimate Equation (1) by OLS including the interaction term in column (2). In this case, the coefficient of unions is no longer statistically significant. As for the coefficient of the interaction term, it is now negative and statistically significant.

\footnotetext{
${ }^{22}$ Note that the existing IV Tobit models (see for instance IVTOBIT implemented in STATA) require that the endogenous variable be continuous, and hence are not suitable for dealing with the endogeneity of dummy-type right-hand-side variables, like our union status indicator.

${ }^{23}$ The estimated coefficients of the control variables are briefly discussed in the Appendix, in which we compare our results with those from standard and random-effect Tobit models.
} 


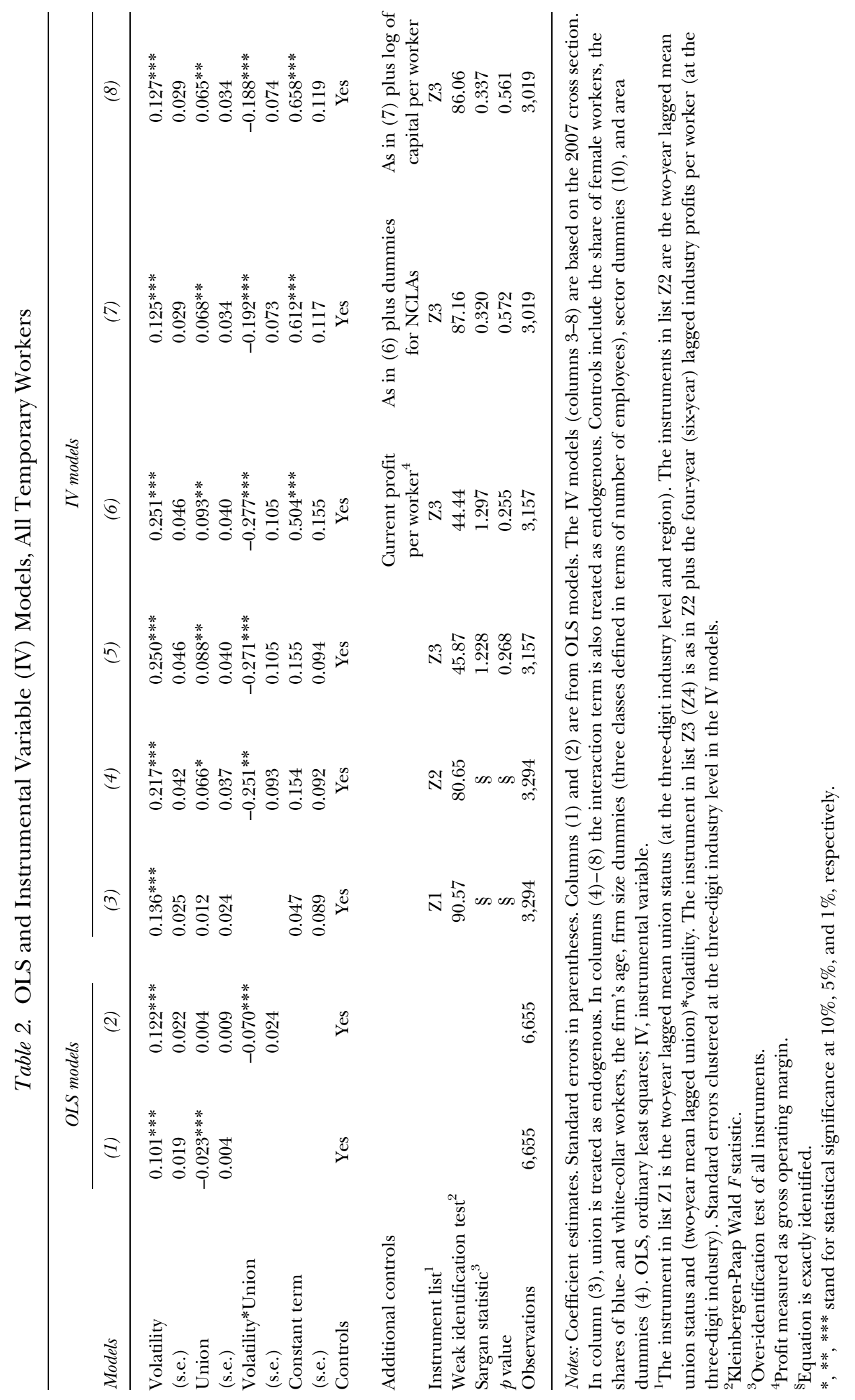


This finding suggests that the union's impact on the use of temporary employment is driven partly by economic uncertainty.

\section{Models}

Given that the exogeneity assumption for the union variable is questionable, for the above-mentioned reasons, we move to a series of IV models, collected in columns (3) to (8) of Table $2 .{ }^{24}$ Column (3) refers to the specification with no interaction between union and volatility. Workplace unionization is treated as an endogenous variable and instrumented with the two-year lagged mean unionization at the industry and regional level, and the equation is exactly identified. The estimates in column (3) confirm the previous finding that volatility has a positive impact on the demand for temporary workers. Note that the direct union effect is now positive, though not statistically significant.

The specification in column (4) includes an endogenous interaction term, which has to be treated as an endogenous variable in the estimation. The additional instrument is given by the interaction between volatility and the two-year lagged mean unionization variable, and the equation is again exactly identified. The estimates largely confirm our previous results: a positive impact of volatility and a negative interaction term between volatility and union presence. Additionally, the main effect of union presence is positive and statistically significant at the $10 \%$ level.

The specification in column (5) adds the four-year lagged industry profits as an additional instrument. The equation is now over-identified, and it is possible to provide a test of over-identifying restrictions. As shown by the Hansen J statistics, we are unable to reject the null hypothesis for the overidentifying restrictions. The results are very similar to the ones in the previous column, but now the main effect of union is also statistically significant at conventional levels.

In the remaining columns, from (6) to (8), additional controls are progressively included for robustness. We begin in column (6) by controlling for current profit per worker, measured at the firm level by the gross operating margin divided by the number of workers. Once a firm's current profitability is controlled for, past industry profits are more likely to be redundant in Equation (1) and hence to constitute a valid instrument.

In column (7) we add a large number of dummies (around 200) for the specific NCLAs applied in the firm; our aim is to control for more detailed industry characteristics than in previous specifications. The dummies also account for any influence arising from the sector-wide bargaining and in consideration of the hierarchical nature of the Italian two-tier bargaining regime. For instance, Italian labor law (Legislative Decree 368/2001) delegates to the various NCLAs the role of fixing the maximum percentage of

\footnotetext{
${ }^{24}$ In the IV models, standard errors are clustered at the three-digit industry and regional level. This choice is consistent with the variability of one of the instruments.
} 
fixed-term workers in a firm's workforce. It is possible to include a large number of NCLA dummies in our IV models, as the definition of these NCLAs is related to, but not entirely overlapping with, the three-digit industry classification we use to compute our instruments. The estimates and diagnostics in column (7) are once again supportive of our earlier conclusions. This supporting result is also the case for our final IV model, in column (8), which adds the firm's capital intensity (the stock of the material fixed assets from the firm's balance sheets, divided by the number of employees) to proxy for a firm's technology.

Before turning to our fixed-effect models, we consider a number of robustness checks for the IV models, which are included in Appendix Table A.1. First, one potential concern regarding our IV identification is that a two-year lag in union status could be correlated with demand conditions two years ago, which in turn are probably correlated with demand conditions in 2007. For this reason, we run additional IV models, by including proxies for productivity and demand shocks for both 2005 and 2007. We do so by inserting controls for the use of materials (intermediate goods) by the firm and/or the industry in our former IV regressions. The rationale is that the use of materials ought to be high when demand is high. This thinking echoes the control function approach used in the estimation of firm productivity equations (e.g., Levinsohn and Petrin 2003) and is in the spirit of the approach followed by Breda (2015) in some of his specifications. Specifically, starting with the most complete IV regression of column (8) in Table 2, we additionally include controls for 1 ) firm-level use of materials in 2005 (column (1) of Table A.1); 2) firm-level use of materials in 2005 and 2007 (column (2) of Table A.1); and 3) both firm-level and industry-level use of materials in 2005 and 2007 (column (3) of Table A.1). Second, although we are unable to exploit further lags in unionization, we can do so for our profit instrument. Hence, in column (4) of Table A.1 we present an additional specification in which we make use of the six-years lagged value of mean industry profits as an instrument, instead of the four-year lag of the baseline estimates. In column (5), the same six-years lagged instrument is obtained from firm-level profits on a slightly smaller sample and a somewhat more parsimonious specification. Our results survive all these robustness checks and are basically unchanged.

\section{Fixed-Effect Models}

A series of linear fixed-effect models are reported in columns (1) to (5) of Table 3. As discussed earlier, fixed-effect models deal with omitted variable bias arising from time-invariant unobserved heterogeneity and provide an alternative identification strategy to the IV models presented so far. We start in column (1) with our baseline FE model, without including the interaction term, while keeping all the time-varying controls as in the OLS and IV models. Note that because the NCLAs applied in a particular firm constitute 
Table 3. Fixed-Effect (FE) Models, All Temporary Workers

\begin{tabular}{|c|c|c|c|c|c|}
\hline \multirow[b]{2}{*}{ Models } & \multirow[b]{2}{*}{ (1) } & \multicolumn{4}{|c|}{ Fixed-effect models } \\
\hline & & (2) & (3) & (4) & (5) \\
\hline Volatility & $0.102^{* *}$ & $0.100 * *$ & $0.157 * * *$ & $0.146^{* * *}$ & $0.144 * * *$ \\
\hline (s.e.) & 0.055 & 0.051 & 0.058 & 0.058 & 0.058 \\
\hline Union & -0.004 & $0.037 * * *$ & $0.042^{* * *}$ & $0.040 * * *$ & $0.041 * * *$ \\
\hline (s.e.) & 0.007 & 0.014 & 0.017 & 0.017 & 0.017 \\
\hline Volatility*Union & & $-0.100 * * *$ & $-0.125^{* * *}$ & $-0.121 * * *$ & $-0.123 * * *$ \\
\hline (s.e.) & & 0.031 & 0.039 & 0.039 & 0.039 \\
\hline Constant term & $-0.010^{*}$ & -0.002 & $-0.011^{*}$ & $-0.013^{* *}$ & $-0.013^{* *}$ \\
\hline (s.e.) & 0.006 & 0.005 & 0.006 & 0.006 & 0.006 \\
\hline Controls & Yes & Yes & Yes & Yes & Yes \\
\hline Additional controls & & & $\begin{array}{l}\text { Material } \\
\text { (in } \log \text { ) }\end{array}$ & $\begin{array}{l}\text { As in (3) plus industry } \\
\text { mean material }{ }^{1}\end{array}$ & $\begin{array}{c}\text { As in (4) plus } \\
\log \text { employment } \\
\text { and log current profit }\end{array}$ \\
\hline Observations & & 2,847 & 2,247 & 2,247 & 2,247 \\
\hline
\end{tabular}

Notes: Coefficient estimates. Standard errors in parentheses. Controls include the share of female workers, the shares of blue- and white-collar workers, the firm's age, firm size dummies (three classes defined in terms of number of employees), sector dummies (10), and area dummies (4). s.e., standard error.

$*, * *, * * *$ stand for statistical significance at $10 \%, 5 \%$, and $1 \%$, respectively.

${ }^{1}$ At three-digit industry and region.

a time-invariant attribute, all our FE models also absorb the specific features of the sectoral collective bargaining and other time-invariant industry characteristics. Column (1) shows that while the coefficient for volatility is still positive and significant, the coefficient of union becomes very small, negative, and insignificant. This finding is consistent with our results so far: at low volatility the union impact is positive; at high volatility the impact is negative. If we exclude the interaction term, the main effect becomes very small (and insignificant) as it reflects what happens at average volatility. Column (2) points out that the central results of the article are restored when reintroducing the interaction term, with a positive coefficient for union and a negative one for the interaction term, both statistically significant.

It is interesting to compare the results in column (2) of Table 3 with the OLS estimates of column (2) in Table 2. What emerges is that controlling for time-invariant unobserved heterogeneity increases the coefficient of the direct union effect, suggesting that firm unobserved heterogeneity, our proxy for the quality of the firm, is positively correlated with union presence and negatively correlated with the share of temporary contracts, as one may have expected.

In column (3) we attempt to control for idiosyncratic productivity shocks that might be correlated to both the firm's demand for temporary workers and workplace unionization. Productivity shocks are typically not observed by the econometrician but might be at least partly anticipated by firms and workers. One simple way to deal with this concern is to rely on a firm's use 
of raw material as a proxy for idiosyncratic shocks. As in the IV models of Table A.1, the idea is that firms increase their use of raw material when they face an increase in the demand for their output. Column (4) further enriches the list of controls by adding industry average consumption of intermediate goods (at the three-digit NACE level). Finally, in column (5) we add a firm's total employment and current profit (in logs) as additional controls. $^{25}$

\section{Sum Up of the Econometric Results and Quantification of the Impacts}

The overall picture is fairly reassuring, with all the qualitative, and to a large extent also the quantitative results, being similar between the IV and the fixed-effects models. ${ }^{26}$ Moreover, since the existing findings in the literature concerning the impact of unions on the use of temporary contract provide ambiguous evidence, our results might be seen as a way to characterize and partially explain this ambiguity, suggesting that the union impact can be positive or negative depending on economic volatility.

In the section titled The Interplay between Unions and Volatility, we discussed various direct and indirect mechanisms for the interaction term between workplace unionization and volatility. Overall, our results on the emergence of a negative interaction term suggest that explanations related to a weakening of workers' cohesion and unions' bargaining position, in turn linked to the fact that temporary workers provide lower support to union activity, dominate the explanations based on a pure buffer stock effect, with its alleged role as a protection mechanism for the insiders.

To quantify this "smoothing effect" of the interaction term, we compute the union effect at different values of volatility. Using the IV estimates in the richer specification of column (8) in Table 2, we obtain that unions increase the proportion of temporary workers by 2.7 percentage points when volatility is low, that is, at the first decile of the volatility distribution. ${ }^{27}$ The same effect is rapidly reduced in the presence of higher volatility: it is virtually zero if volatility is at the median and becomes negative $(-5.1$ percentage points) when volatility is high (at the 90 th percentile). ${ }^{28}$ Similar effects are obtained with the FE estimates: using the estimates in column (5) of Table 3 , the union impact is positive (1.6 percentage points) at low volatility (defined as above), 0 at mean volatility, and negative ( -3.5 percentage points) at high volatility.

\footnotetext{
${ }^{25}$ Profits, material, and the stock of capital are all variables computed, for each firm and year, from the AIDA data set. Hence, they are firm-specific and time-varying.

${ }^{26}$ As a robustness check we include in the Appendix the estimates derived using standard and random-effect Tobit models, which also provide a consistent picture of the results obtained using linear models.

${ }^{27}$ Notice that since volatility never reaches zero, the main effect of unions does not have a natural economic interpretation in the estimates.

${ }^{28}$ Given the high significance of the underlying estimated coefficients, all these average treatment effects are also statistically significant.
} 


\section{Contract Type Matters: Training Temporary Contracts versus Non-Training Temporary Contracts}

In this section we investigate the existence of any relevant heterogeneity across two different types of temporary contracts: non-training compared to training temporary contracts. We focus on this heterogeneity because in most European countries, temporary contracts are often, though not in all cases, associated with training and/or apprenticeship features (Eurofound 2014; Cedefop 2016). This heterogeneity can play a crucial role for firms, which can decide to use strategically the two types of contracts depending on the firms' goals in human resource practices, with different welfare implications from the workers' standpoint (e.g., Berton et al. 2011).

Following our earlier discussion in the section titled Econometric Analysis, we present in parallel and compare the results based on both IV models and FE models. We believe that the analysis carried out in this section is of interest because most of the papers in the literature do not distinguish between types of temporary contracts, yet unions (as firms) might perceive and treat the various types in different ways.

We begin by discussing the results of IV estimations of Equation (1) for non-training temporary contracts (column (1)) and for training temporary contracts (column (2)) in Table 4. The specification and list of instruments is the same as before (see column (6) in Table 2).

Both sets of estimates clearly show that the effects of volatility and union presence are markedly heterogeneous across contract types. The effect of volatility is large and statistically significant only for non-training temporary contracts, whereas it is 10 times smaller and not statistically significant for training temporary contracts. This finding is consistent with the dissimilar role of the two contracts from the firm's standpoint. In coping with a volatile economic environment in the presence of a high level of protection for permanent workers, it is cost effective for firms to rely on non-training temporary contracts rather than contracts with a training clause, as the training investment would be lost upon the temporary worker's dismissal.

The effect of union presence is positive and statistically significant for non-training contracts and negative and not significant for training contracts. This finding can also be rationalized on the basis of the nature of the two types of contracts and may reflect both the interests of the unions and the firms. The unions have an interest in the presence of a positive share of the non-training temporary contracts, which can in principle offer some protection to permanent workers. By contrast, the training contracts cannot credibly work as a buffer to protect insiders, as firms will be less willing to sacrifice their training investments to accommodate the interests of the union. Moreover, in the presence of a union, firms as well may have an interest in hiring on the cheaper type of temporary contracts (i.e., those that carry no training obligations) to countervail any union-driven labor cost push. 


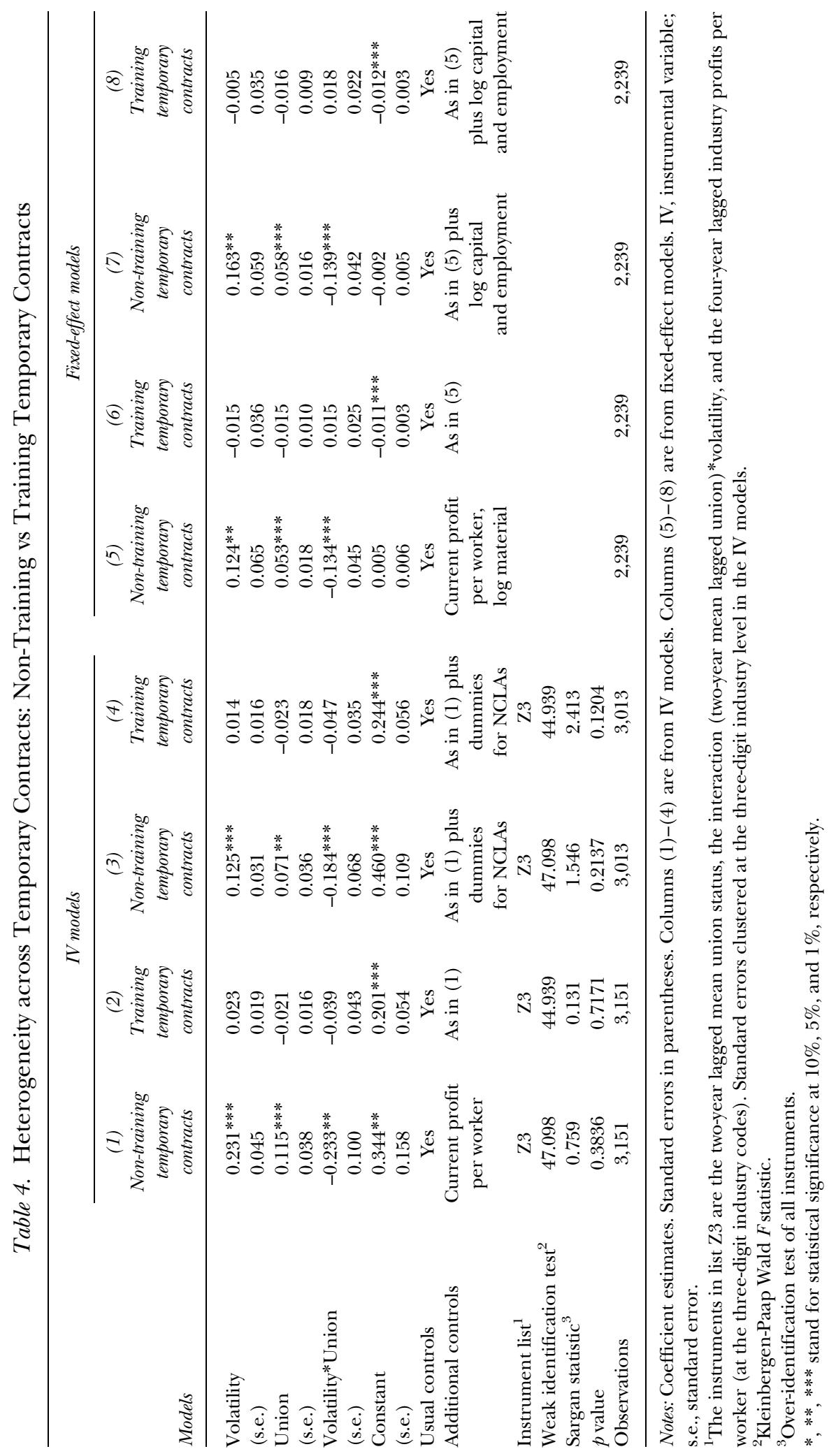


The sign of the interaction effect further qualifies these findings. As discussed in the section The Interplay between Unions and Volatility, one potential explanation for the negative interaction term is that, in a volatile economic environment, the unions become more mindful about the loss of bargaining power because of the high fraction of temporary workers. Although temporary contracts are used by firms to cope with volatile economic environments, the temporary workers are less prone to engage in industrial relations (typically organized by permanent workers), and their presence is thus expected to weaken the strength or "voice" of the unions in the bargaining process. This effect clearly emerges in the case of nontraining temporary workers, who are expected to engage even less in union activity and to leave the firm more easily than training temporary workers, as volatility increases. Other supporting mechanisms are more indirect, as discussed earlier, and emphasize the reduced need by firms to use the more disposable type of temporary employment when, because of increased volatility, the unions might moderate their wage claims and provide more internal employment flexibility. Such an approach embraces a more cooperative attitude with respect to the management.

In columns (3) and (4) of Table 4, we display the estimates of richer specifications that add the NCLA dummies. All our results for non-training temporary contracts are confirmed, whereas no union or volatility effects are detected for training temporary contracts.

The rest of Table 4, columns (5) to (8), shows the results obtained with selected specifications of FE models, estimated separately for the two types of temporary contracts. Columns (5) and (6) are based on a rich specification that controls for the same baseline list of controls as in Table 2, plus firm-level profits per workers and usage of intermediate goods (log materials). Columns (7) and (8) report the results for corresponding models that also control for a firm's capital stock and total employment. Once again, a consistent picture emerges with respect to the results discussed earlier, in terms both of the sign of our relevant variables and, though to a lesser extent, of the estimated magnitudes.

\section{Conclusions}

In this article, we focus on the interplay between unions and demand volatility in driving the propensity by firms to use temporary contracts. Using Italian firm-level data and an identification strategy based on a series of IV and fixed-effect models, in parallel, we obtain the following results.

First, volatility has a positive impact on the firm's use of temporary contracts. This effect is consistent with the previous literature showing that volatility encourages firms to employ temporary workers to adjust the labor input more easily.

Second, although the impact of workplace unionization is not statistically significant in the baseline estimates, a clear pattern emerges when we use a 
specification that includes an interaction term with volatility. In particular, we find that the impact of workplace unionization is positive for low levels of volatility and negative for high levels. In such a framework, unions are able to smooth the impact of volatility for firms, with respect to nonunion firms. We provide a wide set of explanations for this novel finding. Since the existing literature so far has derived only mixed evidence concerning the impact of unions on temporary contracts, our results might be seen as a way to characterize and partially explain this inconclusive evidence, suggesting that the union impact may crucially depend on economic volatility.

Third, the effects of unions and volatility are heterogeneous across types of temporary contracts. The presence of unions per se increases the demand for non-training temporary contracts, as does a higher demand volatility, yet these effects are never detected in the case of training temporary contracts. The negative interaction effect is also only statistically significant for non-training temporary contracts. We have argued that these findings are attributable to the different nature of the two contractual arrangements. In particular, non-training temporary contracts are typically used by firms and are possibly encouraged by unions as a buffer stock for insider workers, that is, standard permanent workers. At the same time, because of their lower prospects as core members of the firm's workforce, workers holding a non-training temporary contract are less likely to engage in union support than are workers holding training contracts. The latter are instead more likely to play a screening role for a firm's core-staff needs, and they are generally more expensive. Hence, training temporary contracts cannot be considered as the prototypical type of disposable temporary contract for both the firms and the union's insiders, and their use by firms does not depend on union status and volatility.

From a methodological point of view, we discussed earlier how European research on the impact of unions is limited by the inability to exploit a sharp econometric identification, as in the case of the US-style union certification elections, and the consequent need to rely on alternative identification strategies, such as IV and fixed-effect models. We acknowledge the limitations of these approaches, in our case partly derived from the data at hand, and stress that we are reassured of the validity of the results because a consistent and mutually reinforcing picture emerges when using either approach.

Despite these potential limitations, we argue that the article contributes to the literature on unions and temporary employment along both a behavioral and a policy perspective. As for the former, we believe our article provides new insights into the role played by worker representation at the workplace in affecting human resource management and firms' personnel policies. We discussed various direct and indirect mechanisms underlying the impact of unions on the firms' use of temporary contracts. Unfortunately, our data do not allow us to disentangle the different mechanisms at work. Nevertheless, our empirical results on the emergence of a robust negative interaction term lead us to conclude that explanations 
related to a unions' weaker-bargaining position (temporary workers provide lower support to unions) dominate explanations based on a pure buffer stock effect. Moreover, our findings about the interaction between unions and the volatility of the economic environment suggest that unions' strategies can actually be significantly different according to local and/or industry market conditions, that is, the economic volatility.

These findings are also relevant from a policy perspective, particularly with reference to the European and Italian debate about the relative merits of centralization versus decentralization in industrial relations. In recent years, policy prescriptions from national and international institutions have recommended a shift away from nationwide sectoral bargaining to firmlevel bargaining in an attempt to recover flexibility and competitiveness for firms. Our results offer some novel insights to this debate. First, our findings might provide additional evidence supporting the decentralization of industrial relations at the local and/or firm level. Intuitively, the higher the decentralization level of the union in the industrial relations, the higher the union's effectiveness in dealing with local market conditions, that is, volatility in our study. This policy argument is new in the literature, because decentralization is usually supported by arguments related to firms' adjustment processes and to incentives for the workforce.

Second, our results have implications for the interactions of different labor market reforms. In recent years, many EU countries have attempted to reduce Employment Protection Legislation (EPL) for permanent workers, partly in an effort to reverse the labor market duality that has emerged since the 1980s. At the same time, many EU countries have reformed their industrial relations to promote firm-level bargaining, to widen its scope, and to enhance derogation to labor legislation and sectoral collective agreements. These concomitant developments in the labor market have led some commentators to express concerns that one perhaps unintended consequence of the prescriptions to promote decentralization might ultimately be an increase in labor market duality, ${ }^{29}$ especially in the face of increased volatility related to globalization, technological change, and the post-Great Recession period. Overall, however, the results of our study indicate that such worries might be misplaced. In particular, our finding of a negative interaction term offers little support to the alleged role of workplace unionization as a contributing factor to labor market duality in the face of rising economic uncertainty for a given level of EPL. This interpretation crucially depends on what happens when volatility increases to the workers who would have had temporary jobs at unionized firms if unions had not

\footnotetext{
${ }^{29}$ In the case of Italy, for instance, policy interventions to reduce EPL for permanent workers have been recently enacted in the so-called Jobs Act, whereas interventions aimed at promoting decentralization and enhancing derogation have been achieved, respectively, by means of fiscal incentives in 2008 and 2011 and by Legislative Decree law 138/2011, article 8. In this new institutional setting, agreements struck at the level of the firm may offset the reduction in EPL for permanent workers stipulated by national legislation and increase the utilization of temporary employment.
} 
followed such a policy of reducing temporary contracts (negative interaction term). Do these workers obtain permanent or temporary jobs elsewhere, or do they become unemployed? Providing further evidence on such issues might be an important task for future research, making use of longitudinal employer-employee data that would allow identification of worker flows when volatility increases in unionized versus nonunionized firms.

\section{Appendix \\ Robustness Checks: Tobit Regressions}

In this Appendix, we include results obtained when using simple Tobit regressions to account for the double-censored nature of our dependent variable. The error term is here assumed to be normally distributed and uncorrelated with the explanatory variables included in Equation (1).

Results are shown in Table A.2. Models (1) and (2) provide Tobit estimates for the pooled sample, that is, waves 2005 and 2007, which we refer to as pooled Tobit. The upper part of the table shows the average treatment effects (ATE), namely, the change in the share of fixed-term contracts associated with a unit change in a given covariate, averaged over the sample distribution of the other covariates in the model. Note that because of the nonlinear nature of the model, computing the ATE of a variable such as union status requires that information be used on both the direct effect of union (coefficient $\beta_{2}$ in Equation (1)) and the interaction effect $\left(\beta_{3}\right.$ in Equation (1)). The lower part of the table therefore also sets out the estimated coefficients for our main variables of interest. ${ }^{30}$

Model (1) in Table A.2 shows that economic volatility has a positive and statistically significant effect on the utilization of flexible contractual arrangements, with an estimated ATE at 0.049. This result implies that a 1 standard deviation increase in volatility (equal to 0.2 ) raises the fraction of temporary workers in the firm by 1 percentage point $(=0.2 * 0.049)$. The estimates in model (1) also show that the presence of a union in the workplace is associated with a lesser use of temporary contracts. Specifically, the ATE of union presence is a statistically significant reduction of 1 percentage point in the use of such contracts.

We then estimate Equation (1) with the inclusion of the interaction term (model (2)). The direct effect of unions is found to be positive, but not

\footnotetext{
${ }^{30}$ It may be interesting to compare the estimated OLS coefficients derived in the article with the related coefficients obtained with the Tobit models of Table A.2. The first thing to observe is the close similarity in the two sets of estimated coefficients; however, note that the magnitude of the estimated ATE is somewhat different. So, while volatility raises the fraction of temporary employment by 0.1 in the OLS models, the impact is reduced by roughly half in the Tobit model. By contrast, the union impact is stronger in the OLS than in the Tobit model. These differences in part relate to the nonlinear nature of the Tobit model; specifically, the Tobit ATE is computed conditionally on the dependent variable lying in the zero-one interval, whereas no such restriction is enforced in computing the OLS ATE. This caveat should be borne in mind also when observing the IV estimates.
} 
Table A.1. Additional IV Results

\begin{tabular}{|c|c|c|c|c|c|}
\hline \multirow[b]{2}{*}{ Specification } & \multicolumn{5}{|c|}{$I V$ models } \\
\hline & (1) & (2) & (3) & (4) & (5) \\
\hline Volatility & $0.165^{* * *}$ & $0.167 * * *$ & $0.129 * * *$ & $0.126 * * *$ & $0.212 * * *$ \\
\hline (s.e.) & 0.030 & 0.030 & 0.033 & 0.034 & 0.050 \\
\hline Union & $0.067^{* *}$ & $0.067^{* *}$ & $0.073^{* *}$ & $0.066^{* *}$ & $0.080 * *$ \\
\hline (s.e.) & 0.033 & 0.034 & 0.035 & 0.033 & 0.040 \\
\hline Volatility*Union & $-0.225^{* * *}$ & $-0.219 * * *$ & $-0.215^{* * *}$ & $-0.217 * * *$ & $-0.230 * * *$ \\
\hline (s.e.) & 0.075 & 0.075 & 0.076 & 0.074 & 0.098 \\
\hline Constant term & $0.648^{* * *}$ & $0.651^{* * *}$ & $0.817 * * *$ & $0.746^{* * *}$ & $0.056^{* * *}$ \\
\hline (s.e.) & 0.123 & 0.122 & 0.128 & 0.127 & 0.172 \\
\hline Controls & Yes & Yes & Yes & Yes & Yes \\
\hline $\begin{array}{l}\text { Additional } \\
\text { controls }\end{array}$ & $\begin{array}{l}\text { As in column (8) } \\
\text { of Table } 2, \text { plus } \\
\text { firm materials } \\
\text { in } 2005\end{array}$ & $\begin{array}{l}\text { As in (1) plus } \\
\text { firm materials } \\
\text { in } 2005 \\
\text { and } 2007\end{array}$ & $\begin{array}{l}\text { As in (2) plus } \\
\text { industry mean } \\
\text { materials in } \\
2005 \text { and } \\
2007^{4}\end{array}$ & $\begin{array}{c}\text { As in (3) } \\
\text { (see text for } \\
\text { list of } \\
\text { instruments) }\end{array}$ & $\begin{array}{c}\text { As in (3) but } \\
\text { with sector } \\
\text { instead of CCNL } \\
\text { dummies (see text } \\
\text { for list of } \\
\text { instruments) }\end{array}$ \\
\hline Instrument list ${ }^{1}$ & $\mathrm{Z3}$ & $\mathrm{Z3}$ & $\mathrm{Z3}$ & $\mathrm{Z} 4$ & $\mathrm{Z} 5$ \\
\hline $\begin{array}{l}\text { Weak identification } \\
\text { test }^{2}\end{array}$ & 66.56 & 66.76 & 70.45 & 62.01 & 61.21 \\
\hline Sargan statistic ${ }^{3}$ & 0.101 & 0.143 & 0.327 & 0.380 & 0.380 \\
\hline$p$ value & 0.750 & 0.705 & 0.567 & 0.537 & 0.537 \\
\hline Observations & 2,921 & 2,921 & 2,921 & 2,921 & 2,410 \\
\hline
\end{tabular}

Notes: Coefficient estimates. Standard errors in parentheses. IV, instrumental variable; s.e., standard error.

${ }^{1}$ The instruments in list $\mathrm{Z3}$ are the two-year lagged mean union status, the interaction (two-year mean lagged union)*volatility, and the four-year lagged industry profits per worker (at the three-digit industry codes). The instruments in list Z4 are as in Z3, but we use a six-year (instead of a four-year) lagged industry profits per worker (at the three-digit industry codes). The instruments in list Z5 are as in Z3, but we use a six-year lagged firm-level (instead of industry-level) profits per worker. Standard errors clustered at the three-digit industry level.

${ }^{2}$ Kleinbergen-Paap Wald $F$ statistic.

${ }^{3}$ Over-identification test of all instruments.

${ }^{4}$ At three-digit industry and region. Materials (firm or industry level) are in logarithms.

$*, * *, * * *$ stand for statistical significance at $10 \%, 5 \%$, and $1 \%$, respectively.

statistically significant; however, as in the Data and Descriptive Statistics section, the coefficient of the interaction term is negative and significant.

In the rest of the Table A.2, we provide estimates of a random-effect Tobit model. In this case, an individual-specific random intercept $\alpha_{i}$ is added to Equation (1) and is assumed to be normally distributed (with zero mean and variance $\sigma_{\alpha}$ ) and uncorrelated with the other explanatory variables. Hence, this model produces consistent estimates only under the rather strong assumption that the $\alpha_{i}$ are uncorrelated with union status. This finding is the main reason that led us to prefer the linear FE model in the main text, as in that case the $\alpha_{i}$ are allowed to be freely correlated with union status. The magnitudes of the estimated coefficients in the randomeffect Tobit are very similar to those discussed earlier for the pooled Tobit, 


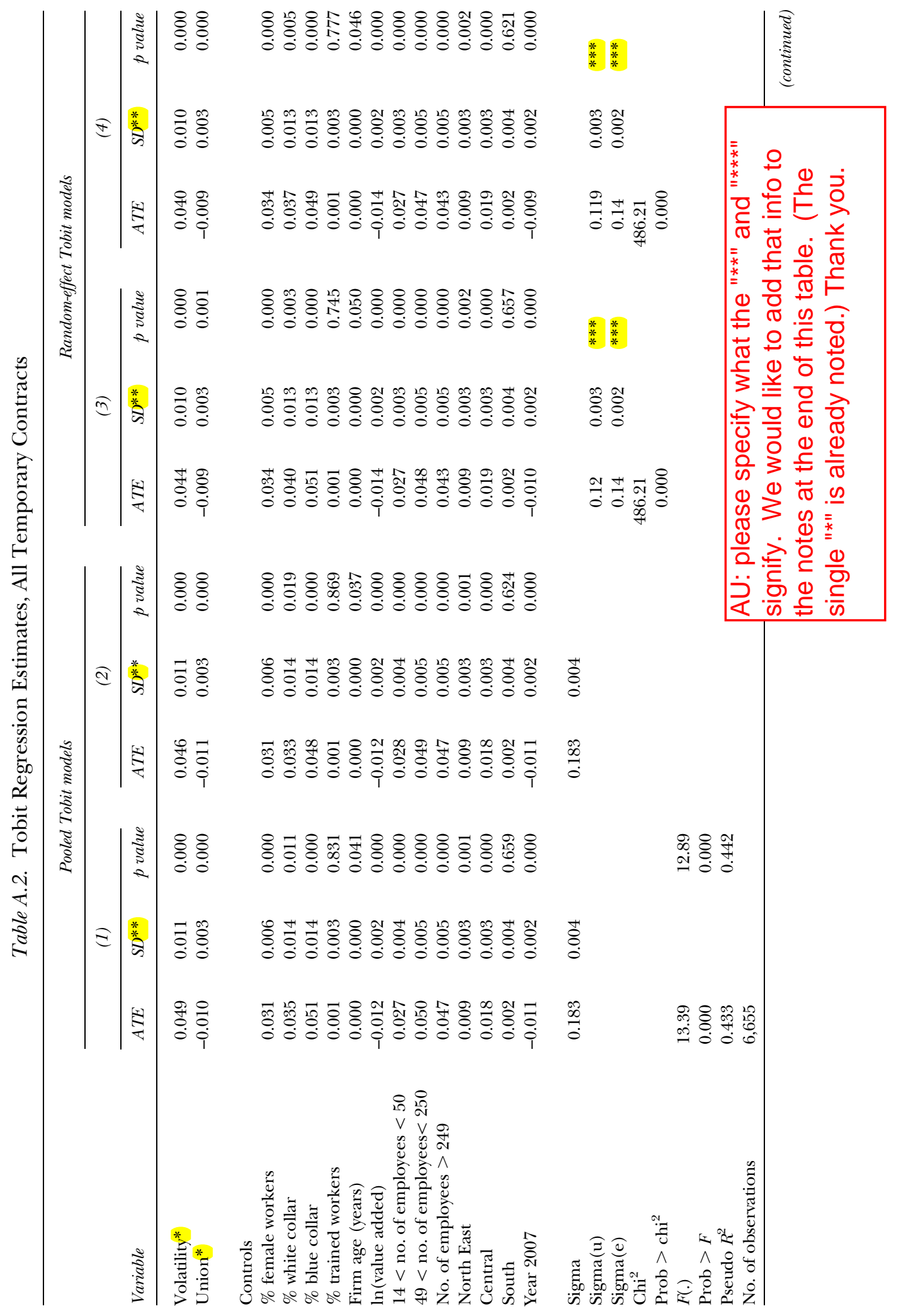




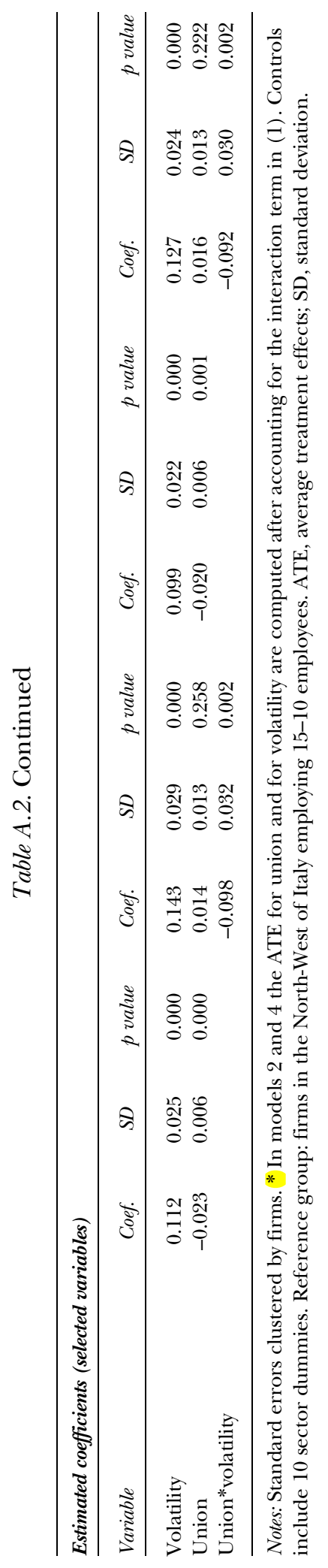


suggesting that unobserved firm heterogeneity is a relatively minor concern in this application.

Table A.2 also displays the estimates of other control variables that could affect the use of fixed-term contracts: the log of value added, firm-size dummies, sectoral specialization, geographical location, and workforce composition. What emerges is that firm productivity (measured by the log of value added) is the only variable that is negatively correlated with the use of fixed-term contracts. By contrast, firm size, the share of female workers, and the share of low-qualified workers (the omitted variable is constituted by executives) are positively associated with the use of total fixed-term contracts. The share of fixed-term contracts is also greater if firms are localized in North-East and Central regions. We do not include coefficients for industry dummies in the table for the sake of space.

\section{References}

Abraham, Katharine G., and Susan K. Taylor. 1996. Firms' use of outside contractors: Theory and evidence. Journal of Labor Economics 14(3): 394-424.

Addison, John T. 2014. The consequences of trade union power erosion. IZA World of Labor Article No. 68. Bonn, Germany: Institute of Labor Economics.

Angrist, Joshua, and Jörn-Steffen Pischke. 2009. Mostly Harmless Econometrics: An Empiricist's Companion. Princeton, NJ: Princeton University Press.

Autor, David H. 2003. Outsourcing at will: The contribution of unjust dismissal doctrine to the growth of employment outsourcing. Journal of Labor Economics 21 (1): 1-42.

Battisti, Michele, and Giovanna Vallanti. 2013. Flexible wage contracts, temporary jobs and firm performance: Evidence from Italian firms. Industrial Relations 52(3): 737-64.

Bentolila, Samuel, and Juan J. Dolado. 1994. Labour flexibility and wages: Lessons from Spain. Economic Policy 18: 55-99.

Bentolila, Samuel, and Gilles Saint-Paul. 1994. A model of labor demand with linear adjustment costs. Labour Economics 1(3-4): 303-26.

Berton, Fabio, Francesco Devicienti, and Lia Pacelli. 2011. Are temporary jobs a port of entry into permanent employment? Evidence from matched employer-employee data. International Journal of Manpower 8: 879-99.

Black, Sandra, and Lisa Lynch. 2001. How to compete: The impact of workplace practices and information technology on productivity. Review of Economics and Statistics 83(3): 434-45.

Blanchard, Olivier, and Augustin Landier. 2002. The perverse effect of partial labour market reform: Fixed-term contracts in France. Economic Journal 112: 214-44.

Bloom, Nicholas, Renata Lemos, Raffaella Sadun, Daniela Scur, and John Van Reenen. 2014. Jeea-Fbbva Lecture 2013: The New Empirical Economics of Management. Journal of the European Economic Association 12: 835-76.

Boeri, Tito. 2012. Institutional reforms and dualism in European labor markets. In Orley Ashenfelter and David Card (Eds.). Handbook of Labor Economics, Vol. 4B, pp. 1173-1236. Amsterdam: North Holland.

Boeri, Tito, and Pietro Garibaldi. 2007. Two tier reforms of employment protection: A honeymoon effect? Economic Journal 117: 357-85.

Booth, Alison L. 1995. The Economics of the Trade Union. Cambridge: Cambridge University Press.

Booth, Alison L., and Francesconi Marco. 2003. Union coverage and non-standard work in Britain. Oxford Economic Papers 55(3): 383-416.

Booth, Alison L., Francesconi Marco, and Frank Jeff. 2002. Temporary jobs: Stepping stones or dead-ends? Economic Journal 112: 189-213.

Breda, Thomas. 2015. Firms' rent, workers' bargaining power and the union wage premium. Economic Journal 125(589): 1616-52. 
Caggese, Andrea, and Vincente Cuñat. 2008. Financing constraints and fixed-term employment contracts. Economic Journal 118: 2013-46.

Cappellari, Lorenzo, Carlo Dell'Aringa, and Marco Leonardi. 2012. Temporary employment, job flows and productivity: A tale of two reforms. Economic Journal 122(562): F188-F215.

Cappelli, Peter H., and JR Keller. 2013. A study of the extent and potential causes of alternative employment arrangements. ILR Review 66(4): 874-901.

Cappelli, Peter, and David Neumark. 2004. External churning and internal flexibility: Evidence on the functional flexibility and core-periphery hypotheses. Industrial Relations 43(1): 148-82.

[Cedefop] European Centre for the Development of Vocational Training. 2016. Governance and financing of apprenticeships. Cedefop Research Paper No. 53. Luxembourg: Publications Office.

Cella, Gian Primo, and Tiziano Treu. 1999. Relazioni industriali e contrattazione collettiva. Bologna: Il Mulino.

Cerruti, Giancarlo 2011. L'evoluzione della contrattazione aziendale nella provincia di Torino tra il 1993 e il 2007. Quaderni di Rassegna Sindacale no. 2: 259-302.

[CNEL] Consiglio Nazionale dell'Economia e del Lavoro. 2007. Lineamenti della contrattazione aziendale nel periodo 1998-2006. Roma: Rapporto.

Costain, James, Juan F. Jimeno, and Carlos Thomas. 2010. Employment fluctuations in a dual labor market. Banco de España Working Paper 1013. Madrid: Banco de España.

Damiani, Mirella, and Andrea Ricci. 2014. Decentralised bargaining and performance related pay: Evidence from a panel of Italian firms. International Journal of Manpower 35(7): 1038-58.

Damiani, Mirella, Fabrizio Pompei, and Andrea Ricci. 2014. Temporary job protection and productivity growth in EU economies. International Labour Review, forthcoming. doi:10.1111/j.1564-913X.2014.00023.x.

D'Amuri, Francesco, and Cristina Giorgiantonio. 2015. The institutional and economic limits to bargaining decentralization in Italy. IZA Policy Paper No. 98. Bonn, Germany: Institute for the Study of Labor.

DiNardo, John, and David S. Lee. 2004. Economic impacts of new unionization on private sector employers: 1984-2001. Quarterly Journal of Economics 119(4): 1383-1441.

Eurofound. 2014. Young people and temporary employment in Europe. European Monitoring Centre on Change, European Union, Ireland, Dublin.

2015. Collective bargaining in Europe in the 21st century. Luxembourg: Publications Office of the European Union.

Francesconi, Marco, and Carlos Garcia-Serrano. 2004. Unions and flexible employment in Britain and Spain: A descriptive note. Industrial Relations 43: 874-82.

Freeman, Richard B., and James L. Medoff. 1984. What Do Unions Do? New York: Basic Books.

Gill, Carol. 2009. Union impact on the effective adoption of high performance work practices. Human Resource Management Review 19(1): 39-50.

Gramm, Cynthia L., and John F. Schnell. 2001. The use of flexible staffing arrangements in core production jobs. Industrial and Labor Relations Review 54(2): 245-58.

Guiso, Luigi, Luigi Pistaferri, and Fabiano Schivardi. 2005. Insurance within the firm. Journal of Political Economy 113(5): 1054-87.

Hatton, Erin. 2014. Temporary weapons: Employers' use of temps against organized labor. ILR Review 67(1): 86-110.

Heery, Edmund. 2004. The trade union response to agency labour in Britain. Industrial Relations Journal 35(5): 434-50.

Holmlund, Bertil, and Donald Storrie. 2002. Temporary work in turbulent times: The Swedish experience. Economic Journal 112: 245-69.

Houseman, Susan N. 2001. Why employers use flexible staffing arrangements: Evidence from an establishment survey. Industrial and Labor Relations Review 55(1): 149-70.

Kahn, Lawrence M. 2007. The impact of employment protection mandates on demographic temporary employment patters: International microeconomic evidence. Economic Journal 117(521): F333-F335.

Kalleberg, Arne L., Jeremy Reynolds, and Peter V. Marsden. 2003. Externalizing employment: Flexible staffing arrangements in U.S. organizations. Social Science Research 32: 525-52. 
Kruse, Douglas L., Richard B. Freeman, and Joseph R. Blasi (Eds.). 2010. Shared Capitalism at Work: Employee Ownership, Profit and Gain Sharing, and Broad-Based Stock Options. Chicago: University of Chicago Press.

Lee, David S., and Alexandre Mas. 2012. Long-run impacts of unions on firms: New evidence from financial markets, 1961-1999. Quarterly Journal of Economics 127(1): 333-78.

Lee, Injae, and Dong-bae Kim. 2005. Unions and the use of flexible staffing in Korea: Evidence from an establishment survey. International Economic Journal 19(2): 223-34.

Levinsohn, James, and Amil Petrin. 2003. Estimating production functions using inputs to control for unobservables. Review of Economic Studies 70 (2): 317-41.

Lotti, Francesca, and Eliana Viviano. 2012. Temporary workers, uncertainty and productivity. Society of Labor Economists. Mimeo. Accessed at http://www.sole-jole.org/13112.pdf.

Malcomson, James M. 1983. Trade unions and economic efficiency. Economic Journal 93(369): $51-65$.

[OECD] Organisation for Economic Co-operation and Development. 2004. Employment Outlook. Paris: OECD. 2008. Employment Outlook. Paris: OECD.

Picchio, Matteo. 2006. Wage differentials and temporary jobs in Italy, 2006. Discussion Paper No. 2006-33. Louvain-la-Neuve, Belgium: Department of Economics, Université Catholique de Louvain.

Pohler, Dionne M., and Andrew A. Luchak. 2014. Balancing efficiency, equity and voice: The impact of unions and high-involvement work practices on work outcomes. ILR Review 67(4): 1063-94.

Saint-Paul, Gilles. 1996. Dual Labor Markets: A Macroeconomic Perspective. Cambridge, MA: MIT Press.

Salvatori, Andrea. 2012. Union threat and non-union employment: A natural experiment on the use of temporary employment in British firms. Labour Economics 19(6): 944-56.

- 2009. What Do Unions Do to Temporary Employment? IZA Discussion Paper No. 4554. Bonn, Germany: Institute for the Study of Labor.

Visser, Jelle. 2002. The first part-time economy in the world: A model to be followed? Journal of European Social Policy 12: 23-42. 